\title{
The Concept of Culture: Bioculturology and Evolutionary Social Sciences
}

\author{
Martin Soukup \\ Katedra teorie kultury (kulturologie) Filozofické fakulty Univerzity Karlovy v Praze, Celetná 20, 11000 Praha 1
}

\section{POJEM KULTURY: BIOKULTUROLOGIE A EVOLUČNÍ SOCIÁLNÍ VĚDY}

\begin{abstract}
ABSTRAKT Předmětem studie je analýza současného stavu konceptu kultury v antropologii, a to v kontextu konstatované krize jak antropologie jako holistické vědy o člověku, tak konceptu kultury jako klíčového epistemologického nástroje v antropologii. Zvláštní pozornost je věnována analýze evolučních teorií kultury, které jsou formulovány v tzv. evolučních sociálních vědách. Autor diskutuje biokulturologii jako výzkumnou strategii, která umožní dialog mezi společenskými a př́rodními vědami, a to zejména s ohledem na evoluční teorie kultury, které jsou stále předmětem diskuzí a sporů. V závěru studie věnuje autor pozornost původu pojmů příroda a kultura a formuluje tezi, že spor o evoluční teorie kultury má kořeny právě v historických kořenech uvedených pojmů.
\end{abstract}

KLÍČOVÁ SLOVA biokulturologie; kultura; antropologie; evoluční sociální vědy

\begin{abstract}
The aim of this paper is to analyze the current state of the concept of culture in anthropology in the context of the crisis both anthropology, as a holistic science of humans, and culture, as a key epistemological tool in anthropology, now face. Special attention is devoted to the analysis of theories of culture in the framework of evolutionary social sciences. Author discusses bioculturology as a potential bridge connecting science and social sciences together with a regard to evolutionary theories of culture that are subject to a certain controversy. In the conclusion the author formulates a thesis that the controversy of evolutionary theories of culture has its origin in the history of the terms "culture" and "nature".
\end{abstract}

KEY WORDS bioculturology; culture; anthropology; evolutionary social sciences

Anthropologists notoriously proclaim that anthropology is a holistic science on humans. In American tradition, developed especially by Boasians, anthropology divides into four subfields: biological anthropology, archeological anthropology, linguistic anthropology and cultural anthropology (see for example Schultz - Lavenda 2005). As anthropologists declare, this kind of division of labor makes the holistic approach in anthropology possible. Every student of anthropology is introduced to the main subject through all its subfields. But alas! The idea of a holistic anthropology disappears when (at the very moment) students graduate. Hence Timothy Ingold worries that "anthropologists have abandoned the study of mankind and that the greater part of what is put out, in the name of such study, confines it to an examination of particular aspects or portions of humanity" (Ingold 1985, 15). In day-to-day anthropological work holistic approach is just like "a pinch of salt" (Ingold 1985, 15). Robert Borofski (2002) in his analysis reveals similar state of affairs showing that a real cooperation across subfields of anthropology is weak. He analyzed studies released in the flagship magazine of anthropology - American Anthropologist. Borofski found out that only 9.5 percent of studies run over frontier of subfields. That is why he designated anthropologists as mythmakers of holistic anthropology. Anthropology is more and more a specialized branch.

Overspecialization is just one of the troubles of anthropology. The second problem anthropology faces is the term of culture itself. In the early $20^{\text {th }}$ century anthropologists shaped their discipline as science on culture and anthropologists have been becoming the specialists on culture (Kuper 2000). Anthropologists shaped culture as theoretical, epistemological and methodological tool enabling them to study the ways of life of different human groups around the world. A vast amount of concepts of culture arose in the first half of $20^{\text {th }}$ century 
(Kroeber - Kluckhohn 1952). In spite of this quantity and the lack of unified definition of culture as such, anthropologists mostly agree on the premise that a culture is learned, based on symbols, a product of history and as such integrates them all together. In other words: culture is the opposite of nature and has its own patterns of existence and evolution. The reflexive trend has been shaping in anthropology since the sixties. In the framework of this trend anthropologists revalued the concept of culture formulated during the first two-thirds of the $20^{\text {th }}$ century as ethnocentric approach to other "cultures". Culture is an emic ${ }^{1}$ concept specifically developed in the course of history of European thought. As such it is linked to philosophical base of Euro-American worldview. Postmodern discussions since the eighties led to the rejection of the concept of culture as a subjective construct made by anthropologists. Consequently at the end of $20^{\text {th }}$ century many anthropologists say "adieu, culture" (Trouillot 2002).

Moreover, anthropology is to some extent a victim of its own success - anthropologists had shaped a successful concept that escaped from the context of anthropology. Culture is now everywhere. Adam Kuper said it succinctly: "Everyone is into culture now" (Kuper 2000, 2). In other words we are witnessing the inflation of the word culture. Keesing formulated in 1974 prognostic viewpoint: “Yanomamö culture,' 'Japanese culture,' the evolution of culture,' 'nature vs culture': we anthropologists still use that word, and we still think it means something. But looking across at our primate relatives learning local traditions, using tools, and manipulating symbols, we can no longer say comfortably that 'culture' is heritage of learned symbolic behavior that makes human humans" (Keesing 1974, 73). Just one year later Edward Wilson published Sociobiology: The New Synthesis. He had defined sociobiology as "systematic study of the biological basis of all social behaviour" (Wilson 1975, 4). Simultaneously Wilson had declared that goal of sociobiology is to "reformulate the social sciences in a way that draws these subjects into the Modern [evolutionary] Synthesis" (Wilson 1975, 4). In spite of the controversy surrounding sociobiology Wilson adopted a new approach to the study of man and culture. Since the seventies, so-called evolutionary social sciences have been developing and spreading through academia. I use the phrase "evolutionary social sciences" as the label for groups of sciences and approaches researching human culture in the framework of the theory of biological evolution. This label reflects the meeting of sciences and social sciences on the frontiers between them and nowadays many scholars use this term (Borgerhoff Mulder et al. 1997; Smith 2000; Smith - Borgerhoff Mulder and Hill 2001). In the framework of the evolutionary social sciences most progressive are the fields of sociobiology, evolutionary psychology,

${ }^{1}$ Anthropological theory distinguishes emic and etic approach. Emic is a strategy of data collection in terms of meanigs from the perspective of the natives. In this kind of research practice anthropologists use natives' concepts. Etic is a strategy of data collection from the observer's perspective. In principle, anthropologists use scientific concepts which are not meaningful to members of researched culture. human behavioral ecology, human ethology, memetics and coevolution genes and culture approach. Representatives of mentioned disciplines developed their own concept of culture, which we could call the evolutionary theories of culture. My analysis of the published papers and books reveals that exponents of the discussed disciplines use the term culture in anthropological sense, but many of them while they use it from the anthropological viewpoint they do so in an unappropriate context. Typical definition of culture in evolutionary social sciences is as follow: Culture is "a sum of all of the artifacts, behavior, institutions, and mental concepts transmitted by learning among members of a society, and the holistic patterns they form" (Lumsden - Wilson 1981, 368). Yes, this is a broad anthropological definition of culture. This kind of definition of culture cultivates Tylorian tradition of "broad definitions with the emphasis on enumeration of content" (Kroeber - Kluckhohn 1952, 43), which is typical for introductory cultural anthropology textbook (Cronk 1999, 4). But authors of the cited definition explain culture as biological adaptation. If anthropologists agree that culture is learned, based on symbols and is a product of history then sociobiological explanation of a culture is the antithesis of anthropology, because sociobiologists come to conclusions that culture is a biological adaptation or that culture follows interests of "selfish genes". The term culture is interpreted in a similar way by the representatives of evolutionary psychology and human ethology.

The representatives of the last two branches also understand culture as a biological adaptation that they study on the level of human behavior that is examined with a regard to the genetic background.

Representatives of human behavioral ecology and coevolutionary approaches use the concept of culture in anthropological sense as well as in the appropriate context but they differ in their approach. They formulate that the relationship between genes and culture are as a peer to a peer - culture is not a biological adaptation, genes do not hijack culture. In human behavioral ecology culture is an adaptive strategy by which human population tries to optimize reproductive success with regard to the conditions of a particular ecosystem. They study culture on the level of human behavior; they think of it as behavioral adaptations to local conditions of ecosystem as well as sociocultural milieu (Smith - Winterhalder 1992). Culture is then a behavioral adaptation.

Coevolutionary approach maintains dynamic mutual relationship between genes and culture. For example William Durham has formulated (1991) five distinctive modes of relationships between genes and culture: cultural mediation, genetic mediation, enhancement, neutrality and opposition. The first two modes are interactive, the last three are comparative (Durham 1991, 205-207). In a sum, it is possible to say that in the interactive mode culture and genes can influence each other. In the comparative mode culture and genes can follow (1) the same goals (enhancement), (2) contradictory goals (opposition), or (3) different, but not contradictory goals (neutrality). Culture is not explained as a product of the evolution of genes. In the coevolutionary approach culture is 
a product of coevolution of genes and sociocultural milieu. The information source in coevolutionary research are both genes and culture with the emphasis on human behavior.

In some respect memetics is similar to coevolutionary approach. Analogous to coevolutionary theories memeticians recognize culture as an independent system of non-biological inheritance. Memeticians based their evolutionary theory of culture on Dawkin's work The Selfish Gene (1976) in which author discussed the concept of universal Darwinism. This scientific theory postulates that the process of evolution possesses universal rules and is in progress under certain conditions wherever in the universe. Dawkins argues that the process of the evolution takes place if there exists a unit of evolution that Dawkins calls replicator. The replicator has three qualities: longevity, fecundity, fidelity. If the replicators do exist then the evolution can take place in the universe and the evolution of genes is the only one of the possibilities. Dawkins coined the meme as the suppositious replicator in order to illustrate principles of universal Darwinism. The meme is a unit of the cultural evolution, basic cultural element. Since the eighties Dawkin's followers have been developing new science of culture based on the concept of universal Darwinism. Memetician theory of culture is established on two separately evolving systems which occasionally affect each other. Culture consists of memes; memeticians then study copying of the memes and their spreading on the level of human behavior (Blackmore 1999; Laland - Brown 2005).

It is not possible to do a detailed analysis of the evolutionary theories of culture in this paper. The previous brief overview indeed reveals both the diversity of the evolutionary theories of culture in the framework of the evolutionary social sciences and its common denominators. We can sum up: the evolutionary social sciences are oriented on human behavior and, with the exception of human behavioral ecology, explain it on the level of cultural or biological heritable information (the genes or the memes). In other words the human behavior and some kinds of the heritable information are the common denominators of the evolutionary theories of culture that were created in the framework of evolutionary social sciences. Aside from some of the evolutionary theories of culture that are the very antithesis of the anthropological understanding of culture, diverse concepts of culture within the nature science only deepen the continuing inflation of this term. Anthropologists in the sixties and seventies urged to recover the concept of culture by redesigning. Clifford Geertz had suggested to narrow the concept of culture insofar that it includes fewer but reveal more (Geertz 1973). Progress of both cultural anthropology and the evolutionary social sciences led to the opposite effect - culture includes more and reveals fewer.

In the previous discussion I underlined four relatively independent sources of crisis of current anthropology as a holistic science. The first one is overspecialization of anthropology and weak cooperation across subfields of anthropology. The second source of crisis is the downfall of the term culture in anthropology itself as it was condemned for being an etno- centric construct and used as a Western tool on non-Western societies.

The third one is the inflation of the word culture. Anthropology coined successful "meme" that carries such a broad meaning that it could in the end cover anything. And if that is the case then culture is a vacant word. The last source of crisis is a broadly discussed concept of culture in the evolutionary social sciences. Its representatives mostly use the term culture in the anthropological sense but generally in an unappropriate context.

I'm not saying "adieu, culture" but of course I worry about future of the concept of culture in anthropology. I personally define culture this way: culture is a system of ideas, sociocultural regulators and artifacts, which are shared and transmitted by members of a particular society and that forces them to think, behave and fix up lives in particular way (Soukup 2004, Soukup 2009). In my point of view the concept of culture should still be in the future the core theoretical, epistemological and methodological tool of anthropology. The culturological perspective could offer some new prospects. In a culturological perspective culture is studied on three structural levels - human nature, sociocultural systems and finally on an individual level. Concisely expressed it Kluckhohn and Murray: "Every man is in certain respects (a) like all other men, (b) like some other men, (c) like no other man" (Kluckhohn Murray 1948, 35). This culturological model (see details Soukup 2004) makes it possible for integral approach to culture with a regard to new operationalization of culture as well as a support desirable for interdisciplinary cooperation between sciences and social sciences.

The theoretical framework of culturology could facilitate understanding between evolutionary social sciences and anthropological viewpoint on the basis of bioculturology which is subfield of culturology. Term bioculturology was coined by American Anthropologist Ino Rossi in the year 1980 as label for subfield of a physical anthropology that focuses on a relationship between cultural and biological phenomena from a perspective of cultural anthropology (Rossi 1980). Bioculturology as the subfield of culturology deals with the study of culture on the level of human nature and explores a mutual relationship between sociocultural system and human nature studied with regard to evolution of genus Homo. Bioculturology evolves from the premise that culture is a non-biological adaptation that parts humans from other living species. But that doesn't mean that humans are independent on their evolutionary past. On the contrary, culture has evolutionary roots and human beings are determinated by traits that have been established in course of the anthropogenesis in the process of biological evolution. Hence bioculturology deals with a broad spectrum of themes concerned with differences between animals and humans beings. Bioculturology further explores the relation between biological and cultural adaptation and evolution, analyses social life of primates, focuses on the solution of the nurture vs. nature argument. On one hand bioculturology rises from the tradition of cultural anthropology and on the other hand from evolutionary social sciences in order to sup- 
port integrated study of humans as biocultural beings. Briefly it might be said that bioculturology adopts relevant findings recognized by sciences and social science and interprets them from the culturological point of view.

Bioculturology might contribute to overcoming above discussed troubles of current anthropology namely in three respects. The first one, bioculturology supports interdisciplinary cooperation between science and social sciences. The second one, it holds culture as main theoretical, epistemological and methodological tool of sciences on man and the last one, it facilitates the overcoming of any misunderstanding between anthropological approach to culture and between evolutionary theories of culture that have a basis in the nature - culture dichotomy. The history of the term culture and nature could reveal the background of the controversy of study of culture in the framework of evolutionary social sciences. The concept of culture was developed by ancient Greek philosophers. Especially philosophers of sophism distinguished order of fysis and nomó. Fysis is order of the world which is independent on human thinking and reorganizing of the universe. Nomó (patterns, rules or laws) is order of the human consensus, convention and agreement. The concept of the care of the soul (epimeleia) was introduced into philosophy by Socrates and Plato and as such was linked to the nomó. The concept of the epimeleia was later adopted by Roman philosophers and Cicero had translated it to the Latin as a culture. In other words, from the very rise of European scientific thought nature (fysis) and culture (nomó) were separated. That is why anthropologists react sometimes hostile to the scientific attempt study culture as a nature; it is same as study nomó as fysis.

\section{REFERENCES}

Blackmore, Susane J. (1999): The Meme Machine. Oxford: Oxford University Press.

Borgerhoff Mulder, Monique et. al (1997): The place of behavioral ecological anthropology in evolutionary social science. In: Weingart, Peter - Mitchell, Sandra D. - Richerson, Peter J. and Maasen, Sabine, eds., Human by Nature: Between Biology and the Social Sciences. New Jersey: Lawrence Erlbaum.

Borofski, Robert (2002): The Four Subfields: Anthropologists as Mythmakers. American Anthropologist, 104(2), s. 463-480.

Dawkins, Richard (1976): The Selfish Gene. Oxford: Oxford University Press. Durham, William H. (1991): Coevolution: Genes, Culture and Human Diversity. Stanford: Stanford University Press.

Geertz, Clifford (1973): Interpretations of Cultures. New York: Basic Books.

Ingold, Timothy (1985): Who Studies Humanity? The Scope of Anthropology. Anthropology today, 1(6), s. 15-16.

Keesing, Roger M. (1974): Theories of Culture. Annual Review of Anthropology 3, s. 73-97.
Kluckhohn, Clyde - Murray, Henry A., eds. (1948): Personality in Nature, Society, and Culture. New York: Alfred A. Knopf.

Kroeber, Alfred L. - Kluckhohn, Clyde (1952): Culture. A Critical Review of Concepts and Definitions. Papers of the Peabody Museum of American Archaeology and Ethnology, Harvard University, roč. 47(1), s. 1-223.

Kuper, Adam (2000): Culture: Anthropologists' Account. Cambridge: Harvard University Press.

Laland, Kevin N. - Brown, Gillian R. (2005): Sense \& Nonsense: Evolutionary Perspectives on Human Behaviour. Oxford: Oxford University Press.

Lumsden, Charles J. - Wilson, Edward O. (1981): Genes, Mind and Culture. The Coevolutionary Process. Cambridge, MA: Harvard University Press.

Malina, Jaroslav - Vašíček, Zdeněk (1990): Archaeology Yesterday and Today: The Development of Archaeology in the Sciences and Humanities. Cambridge: Cambridge University Press.

Rossi, Ino, ed. (1980): People in Culture: A Survey of Cultural Anthropology. New York: Praeger.

Schultz, Emily A. - Lavenda, Robert H. (2005): Cultural Anthropology: A Perspective on Human Condition. New York: Oxford University Press.

Smith, Eric A. (2000): Three Styles in the Evolutionary Analysis of Human Behavior. In: Cronk, Lee - Chagnon, Napoleon and Irons, William, eds., Adaptation and Human Behavior. New York: Walter de Gruyter, Inc.

Smith, Eric A. - Borgerhoff Mulder, Monique and Hill, Kim (2001): Controversies in the evolutionary social science: a guide for the perplexed. Trends in Ecology \& Evolution, 16(3), s. 128-135.

Smith, Eric A. - Winterhalder, Bruce (1992): Evolutionary Biology and Human Behavior. New York: Aldine de Gruyter.

Soukup, Martin (2009): Základy kulturní antropologie [Essentials of Cultural Anthropology]. Praha: Akademie veřejné správy.

Soukup, Václav (2004): Dějiny antropologie [History of Anthropology]. Praha: Karolinum.

Trouillot, Michel-Roph (2002): Adieu, Culture: A New Duty Arises. In: Fox, Richard - King, Barbara J., eds., Anthropology beyond Culture. Oxford: Berg.

Wilson, Edward O. (1975): Sociobiology: The New Synthesis. Cambridge, MA: Belknap Press of Harvard University Press.

\section{AUTHOR}

Soukup, Martin (26 March 1977), Czech culturologist and cultural anthropologist. Assistant professor of Department of Cultural Studies (Culturology) at The Faculty of Arts, Charles University in Prague. He also teaches at The Prague College of Psychosocial Studies. He focuses on history, methodology and theory of anthropology, bioculturology and philosophy of man and culture. Soukup is particularly interested in the cultural area of Melanesia. He undertook anthropological pre-research in Papua New Guinea in three local communities - Wannang (Madang Province), Kegeslugel (Chimbu Province) and Yawan (Morobe Province). Besides number of papers and articles, he is also the author of the textbook Essentials of Cultural Anthropology (2009, in Czech) and monograph Bioculturology: Evolution and Culture (2010, in Czech).

Contact: PhDr. Martin Soukup, Ph.D. The Department of Cultural Studies (Culturology), Faculty of Arts, Charles University in Prague, Celetná 20, 11000 Prague 1, e-mail: martin.soukup@ff.cuni.cz. 